https://doi.org/10.15407/ujpe65.3.196

O.M. NAVOZENKO,${ }^{1}$ V.M. YASHCHUK, ${ }^{1}$ YU.P. PIRYATINSKI,${ }^{2}$ D. GUDEIKA, ${ }^{3}$ A.P. NAUMENKO ${ }^{1}$ YU.L. SLOMINSKII ${ }^{4}$

${ }^{1}$ Faculty of Physics, Taras Shevchenko National University of Kyiv (64/13, Volodymyrs'ka Str., Kyiv 01601, Ukraine; e-mail: a.navozenko@ukr.net)

${ }^{2}$ Institute of Physics, Nat. Acad. of Sci. of Ukraine (46, Nauky Avenue, Kyiv 03028, Ukraine)

${ }^{3}$ Department of Organic Technology, Kaunas University (19, Radvilenu Pl., LT-50254 Kaunas, Lithuania)

${ }^{4}$ Institute of Organic Chemistry, Nat. Acad. of Sci. of Ukraine (5, Murmans'ka Str., Kyiv 02660, Ukraine)

\title{
THE PECULIARITIES OF SINGLET ELECTRONIC EXCITATION ENERGY TRANSFER PROCESSES IN Alq ${ }_{3}$ FILMS $^{1}$
}

\begin{abstract}
The absorption and luminescence of new boron-containing dyes in two-component films of $\mathrm{Alq}_{3}$ (matrix)-dye(impurity) (obtained by the method of thermal vacuum deposition) are studied. The comparison of the spectra of absorption, fluorescence, and fluorescence excitation of a dyes in one-component solutions and double-component films shows the existence of the effective electronic excitation energy transfer (EEET) from the matrix to dye molecules. Timeresolved spectra of two-component films also manifest strong EEET in these systems. For the

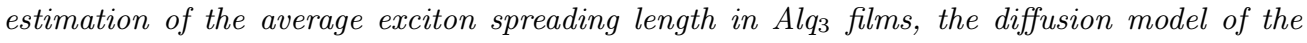
motion of singlet excitons is used. The diffusion coefficient is evaluated using time-resolved spectroscopy. The optimum concentrations of dyes in a light-emitting layer of OLED are evaluated based on experimental data and the used model of EEET.
\end{abstract}

Ke y w ords: boron-containing cyanine dyes, vacuum deposition, Alq 3 -thin films, fluorescence, EEET, singlet excitons, OLED.

\section{Introduction}

Thin organic films have gained enormous interest because of their application in semiconductors devices such as organic light-emitting devices (OLEDs), solar cells and field effect transistors [1]. The new class of power-saving OLEDs requires the search of new materials efficiently transforming the electric energy to the visible light, presenting a good possibility to tune the color of emitted radiation, and being easy and cheap to synthesize. These materials can also be used in

(C) O.M. NAVOZENKO, V.M. YASHCHUK, YU.P. PIRYATINSKI, D. GUDEIKA, A.P. NAUMENKO, YU.L. SLOMINSKII, 2020 solid-state lighting sources for new color displays and as a backlight in LCD monitors [2]. The outstanding OLED energy conversion performance (fraction of the electric energy transformed to the visible light) is ensured by a well-chosen combination of many layers among which is a light-emitting layer. This layer is a thin organic film that often consists of doublecomponents: matrix and impurity. Doping a small amount of a dye with high quantum yield into an organic light-emitting layer can lead to significant

1 The paper was presented at XXIVth Galyna Puchkovska International School-Seminar "Spectroscopy of Molecules and Crystalls" (August 25-30, 2019, Odesa, Ukraine).

ISSN 2071-0194. Ukr. J. Phys. 2020. Vol. 65, No. 3 
changes in the color of luminescence and to a total improvement of the general device properties (e.g., quantum efficiency, lifetime, etc.). The efficiency of the energy transfer from the matrix to dye molecules in the light-emitting layer of OLED, as well as the quantum yield of the luminescence of dyes, belongs to the main factors that determine the total OLED efficiency [3]. This paper presents the study of the spectral properties of tris-(8-hydroxyquinoline)aluminum $\left(\mathrm{Alq}_{3}\right)$ and several dyes and the singlet EEET processes in "matrix-impurity" composite films.

\section{Materials and Methods}

The structure formulas of impurity dyes I, II, III, IV and the $\mathrm{Alq}_{3}$ matrix are presented on Fig. 1. These dyes were synthesized at the Department of Color and Structure of Organic Compounds of the Institute of Organic Chemistry of the NAS of Ukraine. Alq ${ }_{3}$ compound was purchased in Sigma Aldrich. The spectral properties of these dyes were studied also in $[4,5]$. Thin films were grown by the thermal evaporation deposition method on a glass microscope slides and quartz substrates at a pressure of the order $1 \times 10^{-4} \mathrm{~Pa}$. Com posite films were fabricated through the co-evaporation of a dye (dopant) together with $\mathrm{Alq}_{3}$ (matrix). Each composite thin film consists of the matrix substance $\left(\mathrm{Alq}_{3}\right)$ and contains one dye (I, II, III, IV) as an impurity. Substrates were chemically cleaned in dimethylformamide and monoethanolamine. The thickness of the films has been controlled using a quartz thickness monitor and subsequently measured by atom force microscopy and were in the interval 500-600 nm. Fluorescence spectra were registered on a spectrofluorometer Carry Eclipse (Varian), and the absorption spectra were registered on a Specord UV Vis. Fluorescence anisotropy spectra were recorded by the single-beam method $[6,7]$ using two Glan prisms as a polarizer and an analyzer (first Glan prism was placed in front of the sample; second prism was placed in front of a photomultiplier). The fluorescence anisotropy $r$ is defined according to the following formula:

$r=\frac{I_{\mathrm{VV}}-\frac{I_{\mathrm{HV}}}{I_{\mathrm{HH}}} I_{\mathrm{VH}}}{I_{\mathrm{VV}}+2 \frac{I_{\mathrm{HV}}}{I_{\mathrm{HH}}} I_{\mathrm{VH}}}$,

where $I_{\mathrm{VV}}$ - intensity of vertically polarized light at the vertical polarization of the excited beam; $I_{\mathrm{HH}}-$ intensity of horizontally polarized light at the hori-

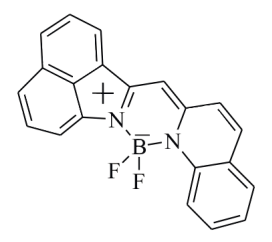

I

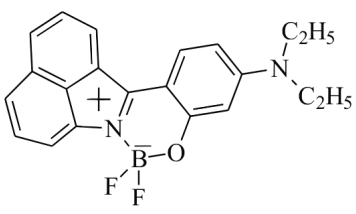

III

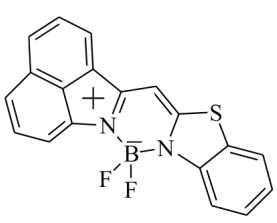

II

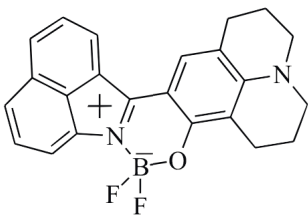

IV

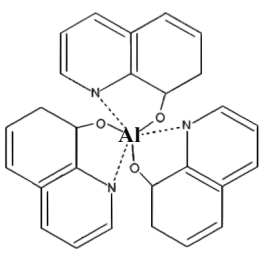

Alq3

Fig. 1. Chemical formulas of emitting centers of dyes (I, II, III, IV) and Alq3 matrix

zontal polarization of the excited beam; $I_{\mathrm{HV}}$ - intensity of horizontally polarized light at the vertical polarization of the excited beam, and $I_{\mathrm{VH}}$ - on the contrary to $I_{\mathrm{HV}}$. All absorption and fluorescence spectra were recorded at room temperature $T=293 \mathrm{~K}$.

Time-resolved PL spectra, kinetics of PL, and timeresolved emission spectra (TRES) were studied using a LifeSpec II spectrofluorometer. To excite a timeresolved $\mathrm{PL}$ in the visible range, we used an EPL405 picosecond pulsed diode laser (Edinburgh Instruments Ltd) with $\lambda_{e}=(405 \pm 10) \mathrm{nm}$, a power of $5 \mathrm{~mW}$, and a pulse duration of $54 \mathrm{ps}$.

\section{Results and Discussion}

\subsection{Absorption and fluorescence} of host $\left(\mathrm{Alq}_{3}\right)$ and guest (dyes) molecules in the solutions and films

The spectra of absorption, fluorescence, and fluorescence excitation of $\mathrm{Alq}_{3}$ in the solution and in onecomponent solid films are shown in Fig. 2. The presented data are in close agreement with the previous paper [4]. The spectra of absorption, fluorescence, 


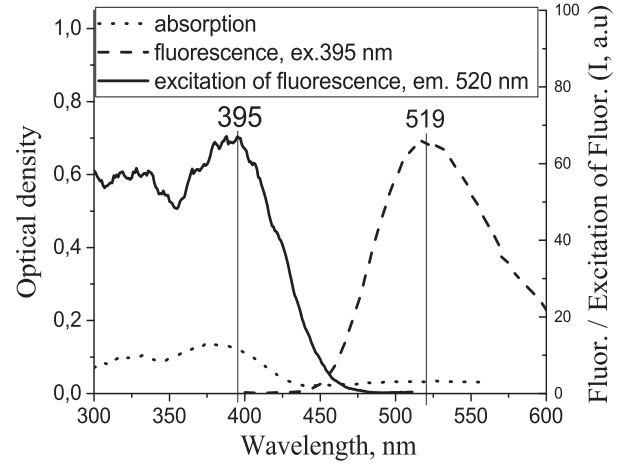

a

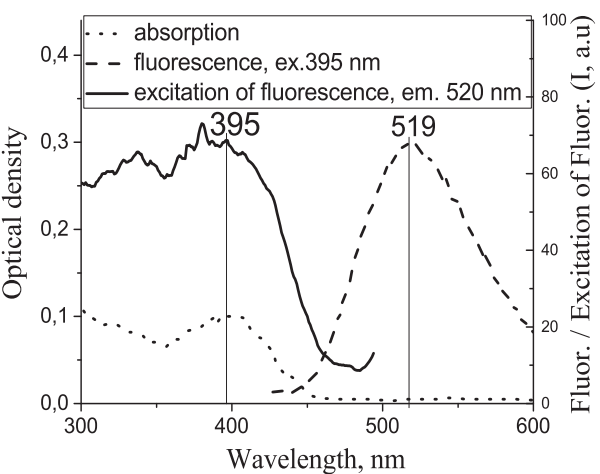

$b$

Fig. 2. Spectra of absorption, fluorescence, and fluorescence excitation of Alq3 in the solution (panel a) and in solid films (panel $b$ )
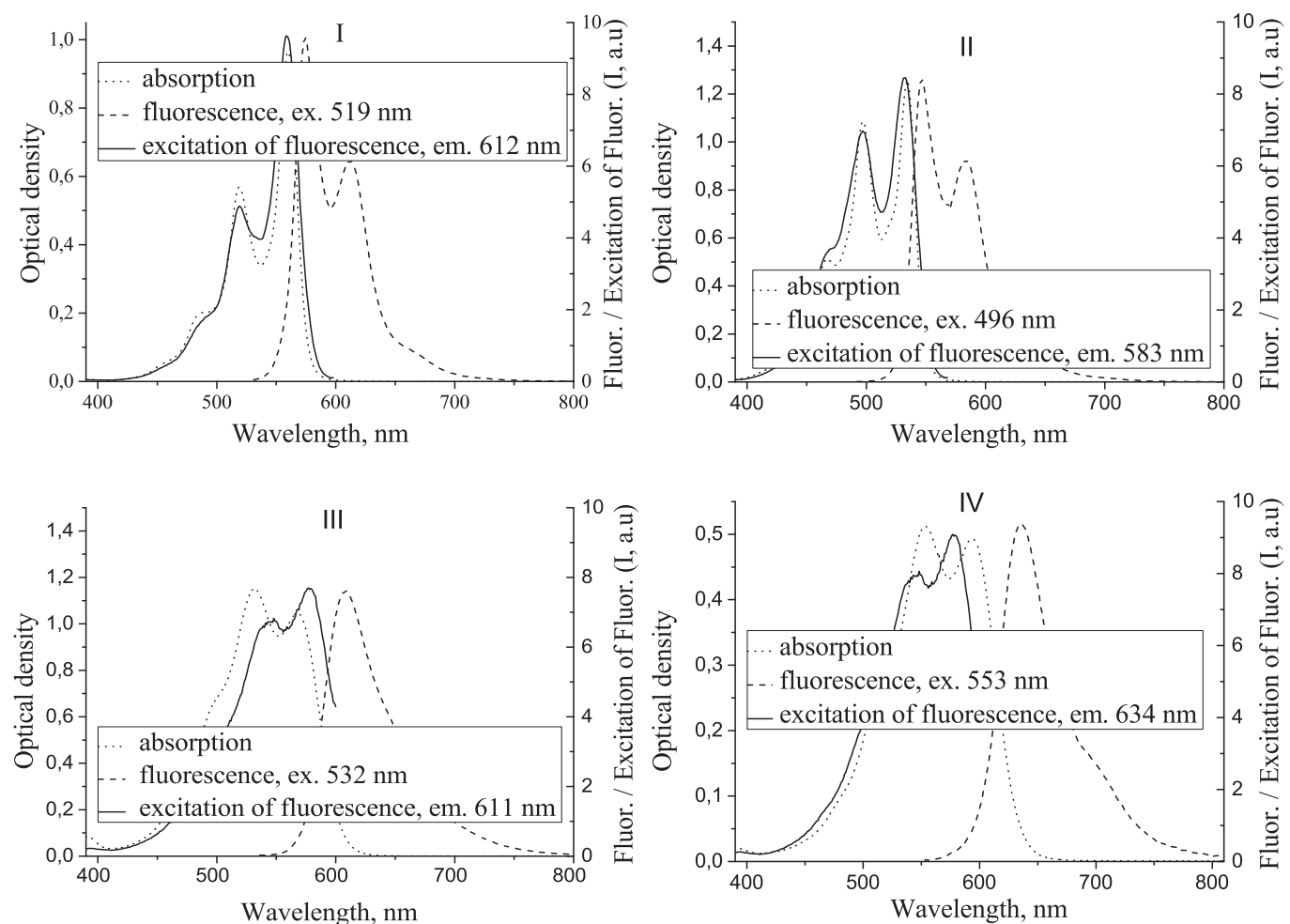

Fig. 3. Spectra of absorption, fluorescence, and fluorescence excitation of dyes I, II, III, IV. Solutions in tetrahydrafuran

and fluorescence excitation of dyes in solutions are shown in Fig. 3. The data presented correspond to [8].

\subsection{Spectra of absorption and fluorescence of the Alq $q_{3}+$ dyes systems (films). Main proofs of singlet EEET in Alq films}

The spectra of absorption, fluorescence, and fluorescence excitation are presented in Fig. 4 . The compos- ite thin films contain two components: $\mathrm{Alq}_{3}$ matrix and dyes (impurities).

For all absorption spectra of composite thin films, the small shift and broadening of absorption maxima are observed in comparison with absorption maxima in solutions. But in general, the dye absorption spectra possess the similar shape and structure in liquid tetrahydrofuran and solid solutions. The fluorescence 

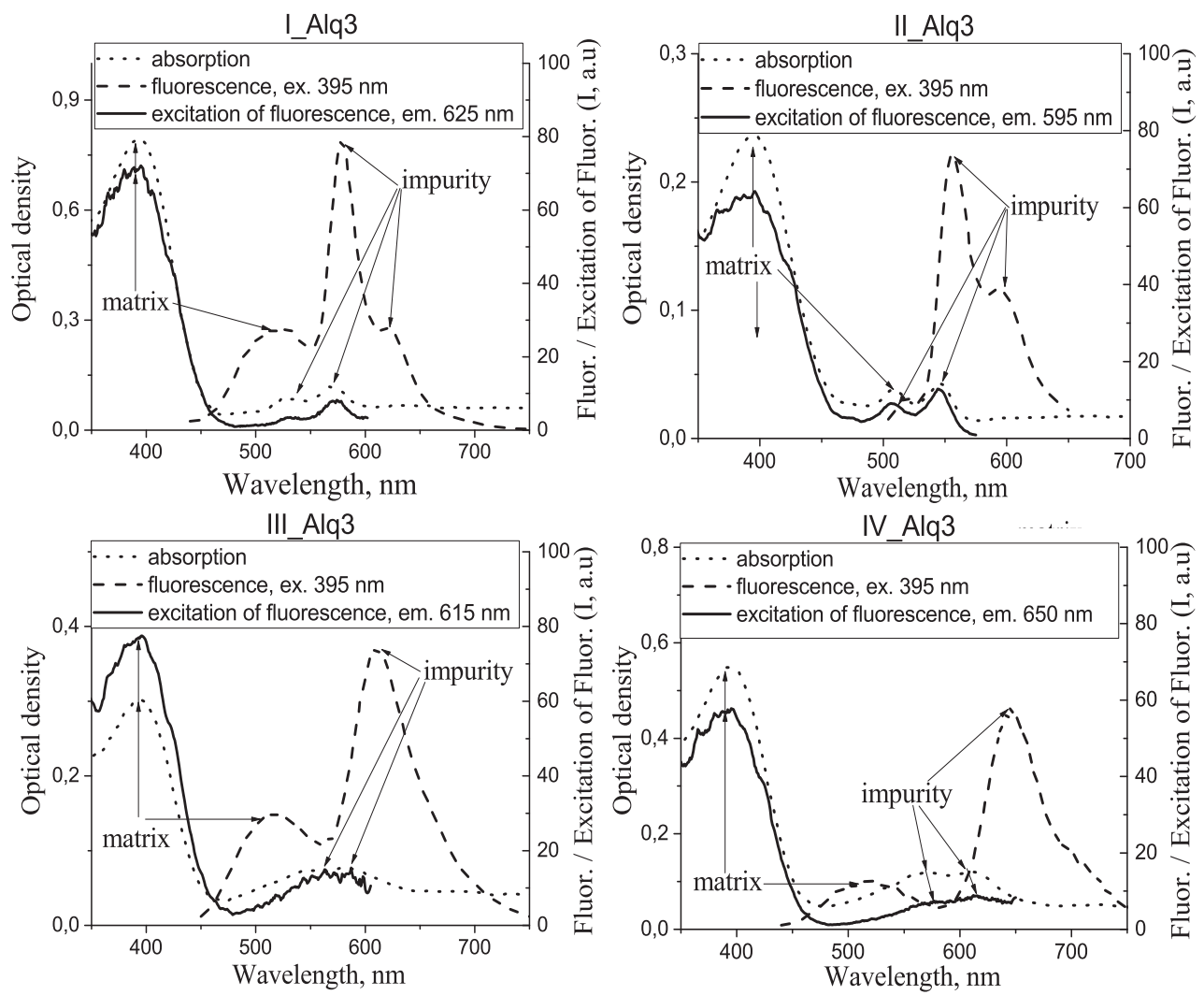

Fig. 4. Spectra of absorption, fluorescence, and fluorescence excitation of Alq3 composite films with dyes I, II, III, IV. Excitation wavelength is equal to $395 \mathrm{~nm}$. The concentration of impurity dye molecules equals $2-4 \%$

spectra of composite thin films (system matrix + dye impurity) and the corresponding fluorescence spectra of dyes in a tetragydrofuran solution are very similar, so dye molecules emit light as separate centers. It can be clearly seen that the fluorescence excitation spectra of composite thin films for each sample manifest the shape close to that of the matrix absorption spectra in a short-wavelength spectral range. The intensity of fluorescence excitation spectra in the matrix absorption spectral range is much higher than the intensity of fluorescence excitation spectra, but in the dye absorption spectral range. It should be noted that the $\mathrm{Alq}_{3}$ extinction coefficient near $395 \mathrm{~nm}$ is significantly higher than the extinction coefficients of dyes (see Fig. 5). This is the first proof of the existence of EEET from host to guest molecules (the evidence that most part of photons are absorbed by matrix molecules, but the most part of electronic excitations are released by the fluorescence emission of dye molecules).

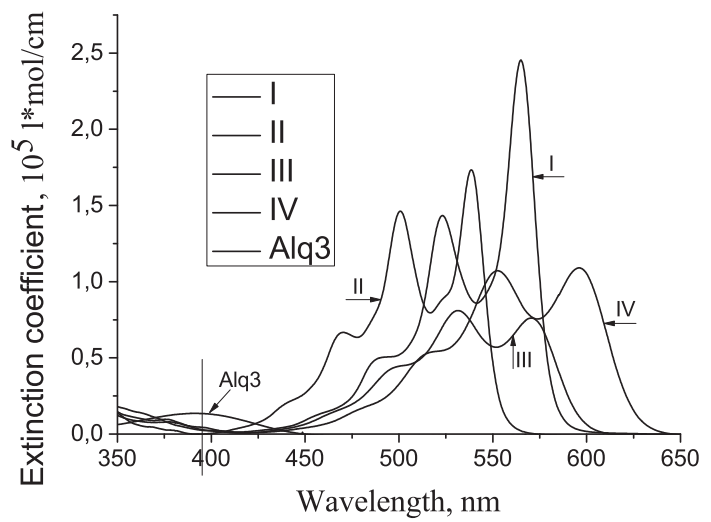

Fig. 5. Absorption spectra of dyes I, II, III, IV and matrix compound $\mathrm{Alq}_{3}$. Solutions in tetrahydrafuran

The second evidence in favor of the existence of EEET is the depolarization of the impurity fluorescence under the excitation in a spectral range, where the matrix absorbs. It is well established that the flu- 

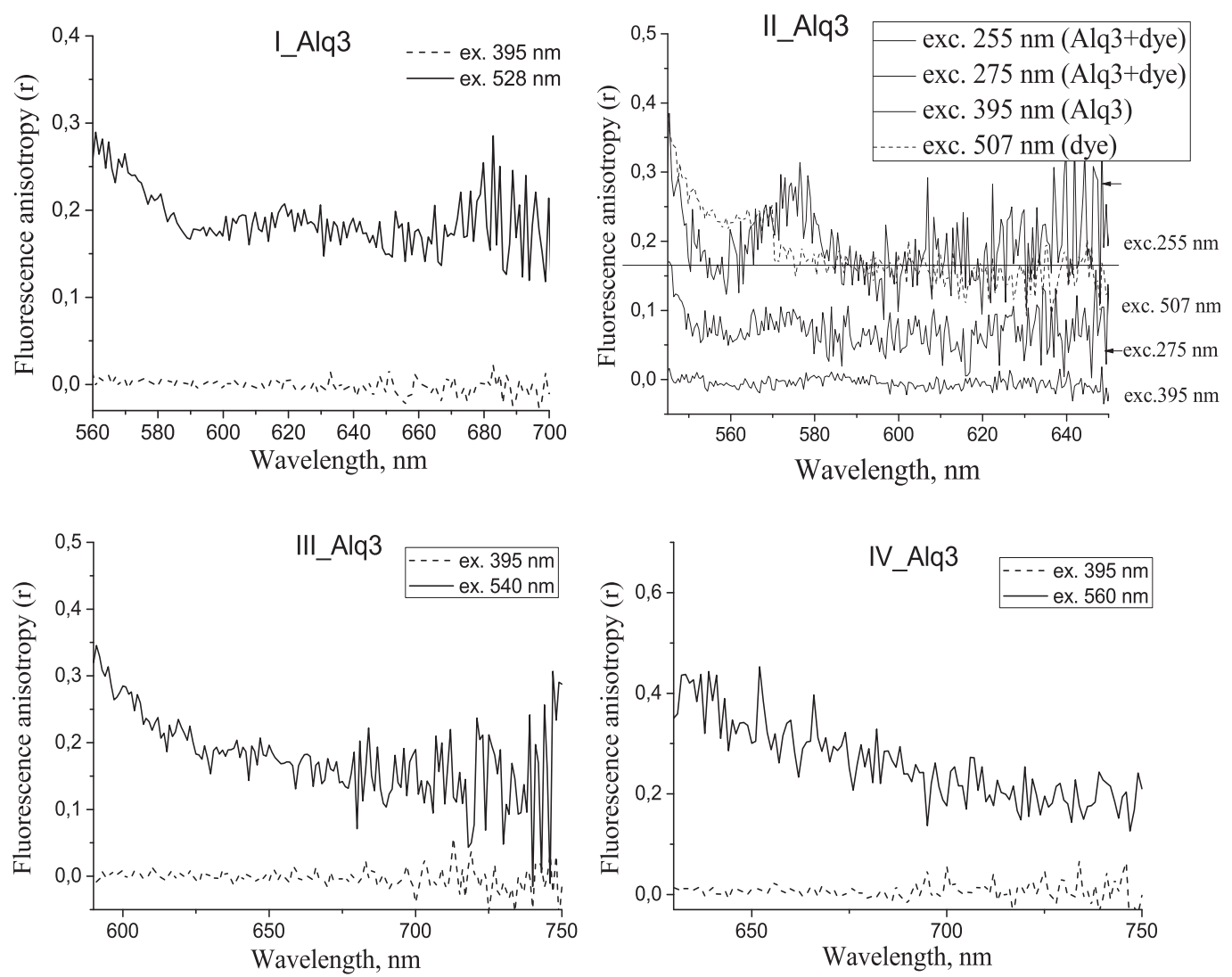

Fig. 6. Fluorescence anisotropy spectra of two-component films Alqu+ dye

orescence of impurity molecules should be depolarized during the electron excitation energy transfer from matrix molecules to impurities. The dependences of the fluorescence anisotropy $r$ for two-component films $\mathrm{Alq}_{3}+$ dyes are shown in Fig. 6. It is seen that the fluorescence polarization is closed to zero (full depolarization of emitted radiation) under the excitation in the matrix absorption range that corresponds to the matrix first electron transition. Under the excitation into the matrix absorption band connected with the second electron transition, the fluorescence polarization is slightly higher (see Fig. 6, II $+\mathrm{Alq}_{3}$ ). This can be explained by the fact that the dye molecules in this spectral range are partially excited that causes the emitted radiation to be partially depolarized. At the same time, the fluorescence polarization is non-zero under the excitation into the dye absorption band, where the matrix does not absorb at all.

The third proof of the existence of EEET from host to guest molecules is given by the time resolved spectra of doped $\mathrm{Alq}_{3}$ films. As follows from these spectra (see Fig. 7), the emission of guest molecules appeared after some time after the emission of host molecules. This time delay is connected with the time of excitation transfer from $\mathrm{Alq}_{3}$ to dye molecules. In addition, in some time after the excitation impulse, the emission of the impurity dominates in the total emission spectra.

\subsection{Analytical description of EEET in a host-guest system based on $\mathrm{Alq}_{3}$.} The model of diffusion of singlet excitons

Preliminary results suggest that the transfer process of electronic excitations between the matrix and dye molecules should exist. For analytical description of EEET in a host-guest system based on $\mathrm{Alq}_{3}$, we took the model of exciton diffusion (that was first proposed by O. M. Faidysh [9]). Let us consider an organic film on which a photon flux with intensity $\Phi_{0}$ falls. Photons generate excitons. Let the absorption coefficient 
of the medium equal $k$. The exciton concentration $(f)$ gradient takes place along the direction of the absorbed photon flux (see Fig. 8).

This is the reason for the exciton diffusion from the upper layers of the organic film into the lower ones. In view of the possibility of the capture of excitons at impurity centers with probability $P$, the following equation can be written:

$\frac{\partial f(x, t)}{\partial t}=D \frac{\partial^{2} f}{\partial x^{2}}+\Phi_{0} e^{-k x}-f(x, t) P$.

The following boundary conditions are used:

$f(0)=f(d)=0$.

The background of such boundary conditions was done in papers $[9,10]$.

Knowing $f(x)$, one can calculate the quantum yield of luminescence and the quantum yields of other processes (e.g., photogeneration of charge carriers, photochemical reaction, etc.). Then the quantum yields of fluorescence of the host compound ( $\left.I_{\text {matrix }}\right)$ and the impurity $\left(I_{\text {dye }}\right)$ are given, respectively, by the expressions

$$
\begin{aligned}
& I_{\text {matrix }}=\frac{k}{1-\frac{k^{2}}{\lambda^{2}}} \times \\
& \times\left[H_{\text {matrix }} \alpha_{\text {matrix }}\left(\frac{1}{k}-\frac{1}{\lambda} \frac{1+e^{-k d}}{1-e^{-k d}} \tanh \frac{\lambda d}{2}\right)\right]+ \\
& +\frac{S}{\lambda_{0}^{2}}\left(\lambda \frac{1+e^{-k d}}{1-e^{-k d}} \tanh \frac{\lambda d}{2}+\frac{1}{k}\right)
\end{aligned}
$$

and [9]

$I_{\text {dye }}=\frac{H \alpha_{\text {dye }} \gamma c_{\text {dye }}}{1+\gamma c_{\text {dye }}} \frac{k}{1-\frac{k^{2}}{\lambda^{2}}}\left[\frac{1}{k}-\frac{1}{\lambda} \frac{1+e^{-k d}}{1-e^{-k d}} \tanh \frac{\lambda d}{2}\right]$,

where

$\gamma=4 \pi R_{\mathrm{eff}} l_{0}^{2}$

is the probability of exciton capture by an impurity molecule, $R_{\text {eff }}$ is the effective radius at which the exciton capture probability is equal to $1 ; l_{0}$ - spreading diffusion length of an exciton; $\gamma$ - coefficient of exciton capture by impurities; $c_{\text {dye }}-$ numerical impurity concentration (molecules in $1 \mathrm{~cm}^{3} ; \alpha_{\text {matrix }}$ and $\alpha_{\text {dye }}-$ fluorescence quantum yields of the matrix and the impurity, respectively); $\lambda=\frac{1}{l_{0}} ; \lambda$ at $c_{\text {dye }}=0$

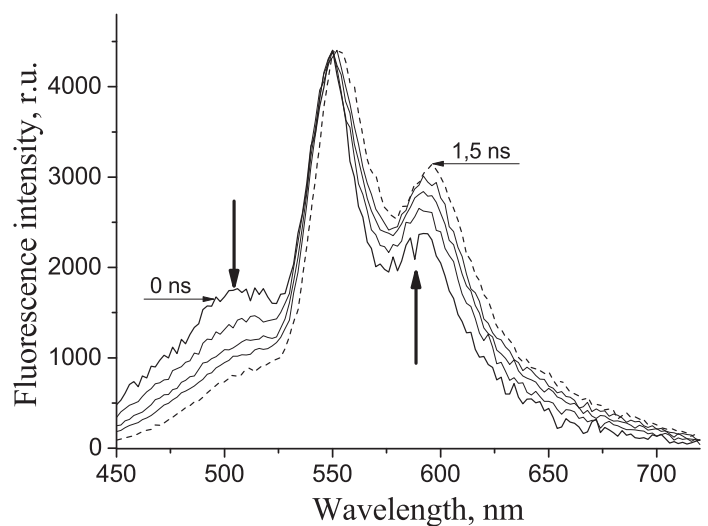

Fig. 7. Time-resolved fluorescence spectra of the dye II-Alq 3 system in the interval 0-1.5 ns (black spectrum corresponds to the starting point of time -0 ; purple spectrum corresponds to the 1.5-ns time). Excitation wavelength is $400 \mathrm{~nm}$. Pulse duration is $50 \mathrm{ps}$. Film thickness equals $340 \mathrm{~nm}$

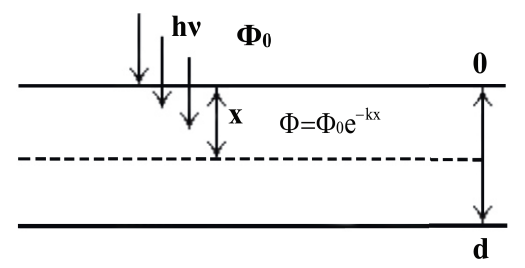

Fig. 8. Illustration to Eq. (2)

equals to $\lambda_{0} ; H_{\text {matrix }}, H$ - constants, which mainly account for the re-absorption influence in the ground state. At low concentrations of traps (impurities), the dependence $\frac{I_{\text {matrix }}}{I_{\text {impurity }}}$ is linear [11]:

$\frac{I_{\text {matrix }}}{I_{\text {impurity }}}=\gamma c_{\text {dye }} \frac{\alpha_{\text {dye }}}{\alpha_{\text {matrix }}}$.

\subsection{Comparison of theory} with experiment. Dependence

of the fluorescence intensity of guest molecules on their concentration in $\mathrm{Alq}_{3}$ films. The average spreading range of singlet excitons in $\mathrm{Alq}_{3}$ films

Comparing the theory [Eqs. (6) and (7)] with experiment, the ratio

$\frac{I_{\text {matrix }}}{I_{\text {dye }}}=F\left(c_{\text {dye }}\right)$

gives possibility to obtain the exciton diffusion spreading length $l_{0}$. It should be noted that $l_{0}$ is connected with the probability of exciton capture by an 

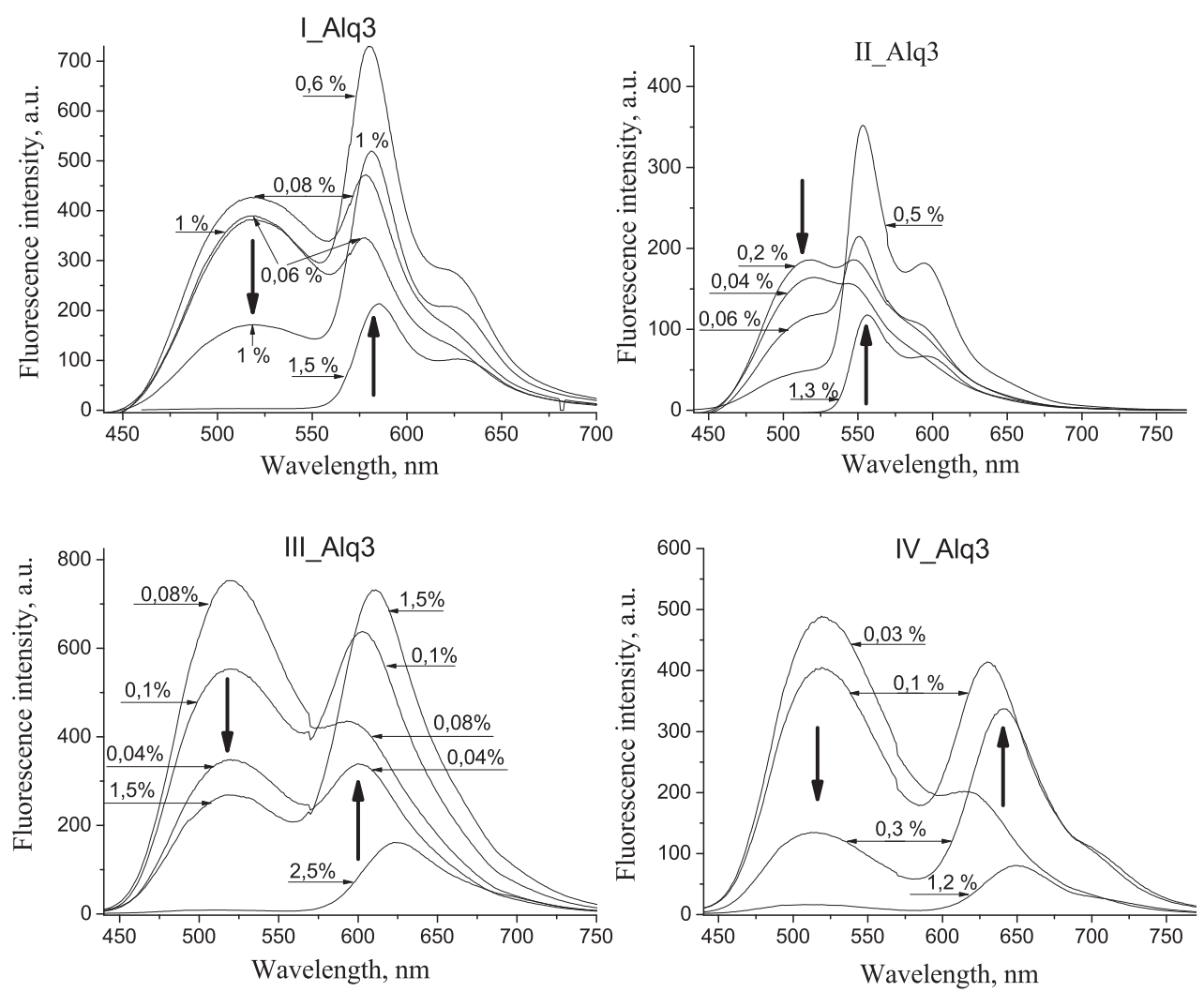

Fig. 9. Fluorescence spectra of two-component films depending on the impurity concentration (I, II, III, IV) in the Alqu matrix. Excitation wavelength $395 \mathrm{~nm}$

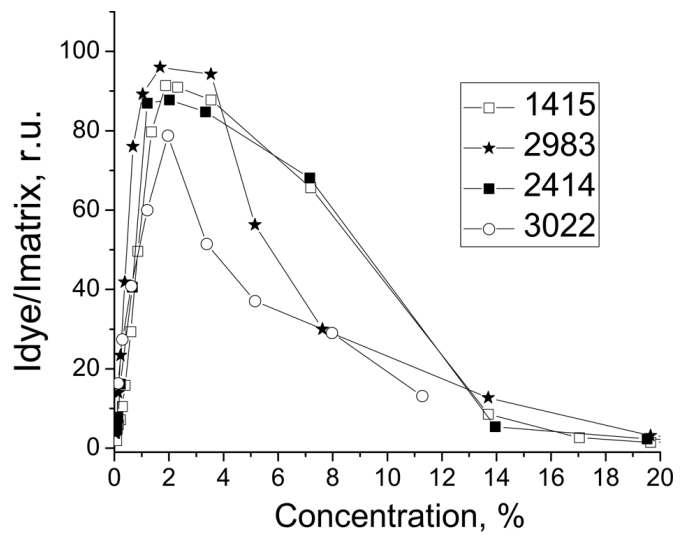

Fig. 10. Relative dependences of the fluorescence intensities of impurity compounds (I, II, III, IV) in the Alq3 matrix depending on the impurity concentration. Excitation wavelength $395 \mathrm{~nm}$

impurity. This can be derived from the previously defined relation for the exciton capture probability

$\gamma=4 \pi R_{\text {eff }} l_{0}^{2}$, where $R_{\text {eff }}$ is the effective radius at which the exciton capture probability is equal to 1 , and is evaluated to be $3.3 \times 10^{-4} \mathrm{~cm}^{2} / \mathrm{s}$. Here, the distance of the elemen-

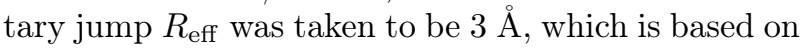
the results of transmission electron microscopy, quantum chemical modeling, and the results obtained in [11-14].

The series of composite thin films were fabricated with different dye concentrations in samples. The photoluminescence (PL) spectra of all composite thin films were recorded using excitation wavelengths which correspond to the maxima of the absorption extinction coefficient of the matrix in the spectral range of the first electron transition (see Figs. 5 and 9).

The ratio of the $\mathrm{PL}$ quantum efficiencies $\left(I_{\text {dye }} / I_{\text {matrix }}\right)$ as a function of the dye concentration loading level is shown in Fig. 10.

As one can see, a linear dependence takes place in the region of small concentrations. The obtained values of singlet exciton spreading lengths are shown in Table.

ISSN 2071-0194. Ukr. J. Phys. 2020. Vol. 65, No. 3 
Exciton spreading lengths in the $\mathrm{Alq}_{3}$ matrix

\begin{tabular}{|c|c|}
\hline Impurity & $\begin{array}{c}\text { Exciton spreading } \\
\text { length, } \AA\end{array}$ \\
\hline I & 150 \\
II & 200 \\
III & 120 \\
IV & 130 \\
\hline
\end{tabular}

The obtained data are close to the value in antracen crystals, where the spreading length is equal to $150 \AA\left(R_{\text {eff }}=3 \AA\right)$ [15]. In [3], the exciton spreading length for $\mathrm{Alq}_{3}$ was found to be approximately equal to $200 \AA$ which is close to our results. The exciton diffusion coefficient is defined according to the formula

$D=\frac{l_{0}^{2}}{\tau}$

and is equal to $3.3 \times 10^{-4} \mathrm{~cm}^{2} / \mathrm{s}$.

It should be noted that the obtained exciton spreading lengths in $\mathrm{Alq}_{3}$ matrix for different impurities differ significantly from one another (see Table). We think that this fact can be explained by the impurity influence on the closest matrix environment, which induces a change of the energy transfer effectiveness in an impurity proximity and a change of the impurity intercept probability of the migrating excitation. The probability of the final energy transfer between the matrix and an impurity depends on the wave function overlap between $\pi$-electron systems (in matrix and impurity molecules) and on the angles between the transition dipole moments of matrix and impurity molecules. During the vacuum deposition, the film formation kinetics may be such that the similar co-locations of impurity molecules and matrix molecules will be possible only for certain impurities. For example, the spatial structure of dye III has a branched methyl group structure, and the exciton spreading length in $\mathrm{Alq}_{3}+$ III is less significantly than the exciton spreading length in the same matrix + planar molecule II [16].

\section{Conclusions}

We would like to emphasize that the obtained results give the possibility to solve some applied problems in the design of OLEDs. One of them is the evaluation of the optimal concentration of a lightemitting impurity. This value can be determined us- ing the spreading length of excitons. The efficiency of EEET from a matrix molecule to guest molecules has to reach the maximum, if the average exciton spreading length equals the average distance between impurities molecules. In this case, all excitons generated in the matrix have to be captured by impurity molecules. Namely, this distance between neighbor guest molecules corresponds to their optimal concentration. The dye doping into a light-emitting layer of OLED leads to a number of advantages over films without dye doping. The doping with cyanine dyes (I, II, III and IV) gives significantly narrower PL spectra than non-doped $\mathrm{Alq}_{3}$ films. This is a significant benefit in full-color display applications, which require saturated red, green, and blue outputs for the color mixing. Using the several impurities in the matrix leads to an extension of the radiation range and can be used in the fabrication of white OLEDs. High efficiency can be achieved by the doping with dye molecules which have high quantum yield and optimal concentration, when the efficient energy transfer from the matrix to dye molecules takes place.

1. W. Brutting. Physics of Organic Semiconductors (WileyVCH, 2005) [ISBN: 3-527-40550-X].

2. T. Takatoshi. OLED Display Fundamentals and Applications (Wiley, 2017) [ISBN: 9781119187493].

3. A. Shoustikov, Y. You, M. Thompson. Electroluminescence color tuning by dye doping in organic light-emitting diodes. IEEE J. Select. Topics Quant. Electr. 4, 3 (1998).

4. O.D. Kachkovsky, V.M. Yashchuk, O.M. Navozenko, A.P. Naumenko, Yu.L. Slominskii. On the nature of the lowest electron transitions in the borine dye derivatives benz[c,d]indole. J. Mol. Struct. 1074, 589 (2014).

5. V.M. Yashchuk, O.M. Navozenko, Yu.L. Slominskii, J.V. Grazulevicius, O.D. Kachkovsky, A.P. Naumenko. Peculiarities of electronic processes in high-fluorescence boron-containing composite films. Ukr. J. Phys. 59, 238 (2014).

6. J.R. Lakowicz. Principles of Fluorescence Spectroscopy (Springer, 2008) [ISBN: 978-0387-31278-1].

7. B. Valeur. Molecular Fluorescence: Principles and Applications (Wiley-VCH, 2001) [ISBN: 3-527-60024-8].

8. O.M. Navozenko, V.M. Yashchuk, Yu.L. Slominskii, O.D. Kachkovsky, A.P. Naumenko, Y.O. Myagchenko. Photophysical properties of novel luminescent dyes: difluoroborate complexes of benz[c,d]indole derivates. Funct. Mater. 19, 504 (2012).

9. I.Ya Kucherov, O.M. Faidysh. Transfer of electron excitation energy in solid organic solutions. Rep. Acad. of Sci. of the Ukrainian SSR 1, 57 (1956).

10. Y. Tamai, H. Ohkita, H. Benten, S. Ito. Exciton diffusion in conjugated polymers: From fundamental understanding 
to improvement in photovoltaic conversion efficiency. Phys. Chem. Lett. 6, 3417 (2015).

11. O.M. Faidysh, V.M. Yashchuk, V.Ya. Pochynok, L.M. Fedorova. Influence of the migration of the electron excitation energy on the luminescence of $\mathrm{N}$-vinylcarbazole and polyvinylcarbazole. Ukr. J. Phys. 21, 1528 (1976).

12. V.M. Yashchuk. Triplet excitons in $\pi$-electron containing polymers. Polimery, 7-8, 475 (1999)

13. Yu.N. Demikhov, O.M. Faidysh, V.M. Yashchuk. Luminescence and the transfer of the singlet excitation energy in a solid monomer of styrene. Optics and Spectroscopy $\mathbf{3 5}$, 646 (1973).

14. Yu.N. Demikhov, O.M. Faidysh, V.M. Yashchuk. The effect of energy transfer of electronic excitation on the luminescence of styrene monomer with an admixture of polystyrene. Optics and Spectroscopy 37, 686 (1974).

15. V.V. Agranovych, I.Ya Kucherov, O.M. Faidysh. Length of the diffusion displacement of excitons in anthracene crystals. Ukr. J. Phys. 2, 61 (1957).

16. O.M. Navozenko, V.M. Yashchuk, Yu.L. Slominskii. Peculiarities of energy transfer in thin films of tris(8hydroxyquinolinato)aluminium complexes. Proceedings of the 18th International Young Scientists Conference "Optics and High-Technology Material Science" Devoted to the 95th Anniversary of Professor M. U. Bilyi (Kiev Univ., 2017).

Received 05.02.20
О.М. Навозенко, В.М. Яшчук,

Ю.П. Пірятинсъкий, Д. Гудейка,

А.П. Науменко, Ю.Л. Сломінсъкий

ОСОБЛИВОСТІ ПРОЦЕСІВ

ПЕРЕНЕСЕННЯ ЕНЕРГІЇ СИНГЛЕТНОГО ЕЛЕКТРОННОГО ЗБУДЖЕННЯ В ПЛІВКАХ Аlq3

Р е з ю м е

Вивчено поглинання та люмінесценцію нових борвмісних барвників у двокомпонентних плівках Alq3 (матриця) барвник (домішка) (отримані методом термічного нанесення у вакуумі). Порівняння спектрів поглинання, флюоресценції, збудження флюоресценції в однокомпонентних розчинах та двокомпонентних плівках показує наявність ефективного перенесення енергії електронного збудження (EEET) від матричних молекул до молекул барвника. Спектри випромінювання двокомпонентних плівок, розділені за часом, також проявляють домінуючу передачу енергії електронного збудження в цих системах. Для оцінки середньої довжини пробігу екситону в плівках Alqз була використана модель дифузійного руху синглетних екситонів. Коефіцієнт дифузії синглетних екситонів було оцінено за допомогою часово-розділеної спектроскопії. Оптимальні концентрації барвників у світловипромінюючому шарі OLED були отримані на основі експериментальних даних та використаної моделі ЕEЕТ. 